LITERATURE REVIEW AND NEED FOR ADDITIONAL STUDY OF SURFACE-WATER QUALITY IN THE CUYAHOGA VALLEY

NATIONAL RECREATION AREA, OHIO

By C. J. Oblinger Childress

U.S. GEOLOGICAL SURVEY

Open-File Report 84-619

Prepared in cooperation with the

NATIONAL PARK SERVICE

Columbus, Ohio 


\section{UNITED STATES DEPARTMENT OF THE INTERIOR \\ WILLIAM P. CLARK, Secretary \\ GEOLOGICAL SURVEY \\ Dallas L. Peck, Director}

For additional information write to:

District Chief

Water Resources Division

U.S. Geological Survey

975 w. Third Avenue

Columbus. Ohio 43212
Copies of this report can be purchased from:

Open-File Services Section Western Distribution Branch U.S. Geological Survey Box 25425, Federal Center Denver, Colorado 80225

(Telephone: (303) 234-5888) 


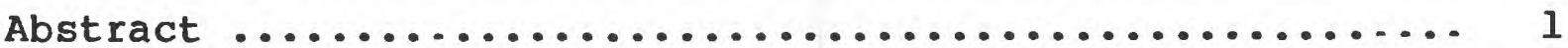

Introduction $\ldots \ldots \ldots \ldots \ldots \ldots \ldots \ldots \ldots \ldots \ldots \ldots \ldots \ldots \ldots$

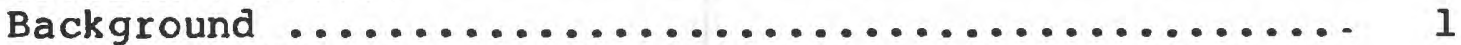



Description of the Cuyahoga River basin ............ 3

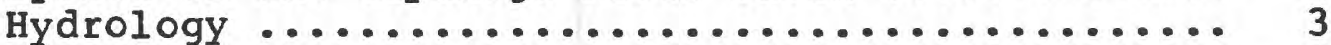



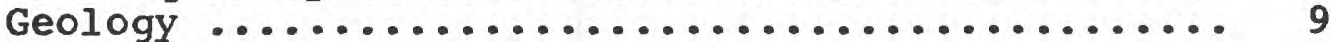

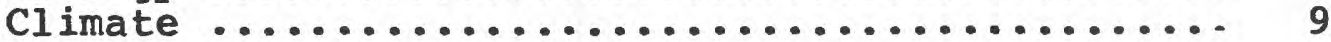

The CVNRA and its management objectives ............. 9



Review of previous studies of the Cuyahoga River ........ 15

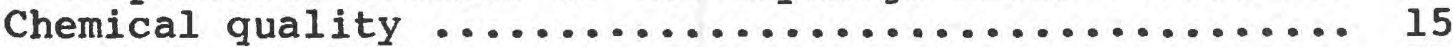

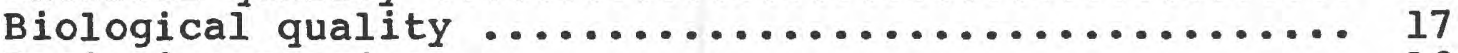

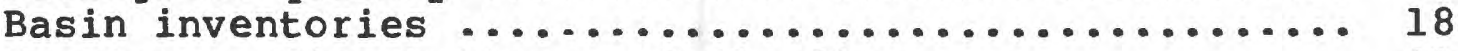

Erosion, sedimentation, and flooding .............. 20

Suggestions for additional study of water quality of

the Cuyahoga River ........................... 21

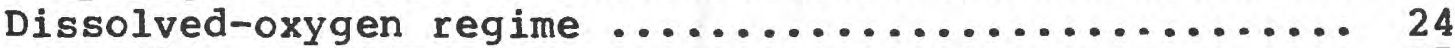



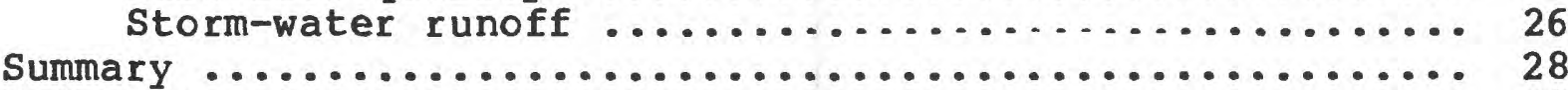

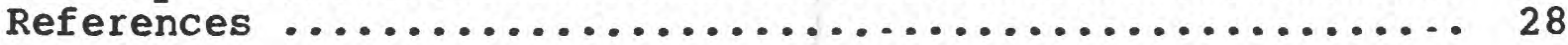

\section{ILLUSTRATIONS}

Figure 1. Map showing the Cuyahoga River basin ........ 2

2. Map showing the Cuyahoga Valley National

Recreation Area ....................... 4

3. Profile of the Cuyahoga River from

Lake Rockwell to Cleveland. Ohio ........... 5

4. Flow-duration curves for the Cuyahoga River at

the old Portage and Independence gages ...... 8

5. Graphs of minimum daily dissolved-oxygen concentrations at old Portage gage. water years 1972 and $1981 \ldots \ldots \ldots \ldots \ldots \ldots . \ldots . \ldots 22$

6. Graphs of minimum daily dissolved-oxygen concentrations at the Independence gage, water years 1972 and 1981

\section{TABLES}

Table 1. Inventory of U.S. Geological Survey gages in



2. Mean discharge for stations within the CVNRA .... 14 


\section{CONVERSION FACTORS}

For the benefit of readers who prefer to use the International System of units (SI). conversion factors for terms used in this report are listed below:



\begin{tabular}{|c|c|}
\hline By & $\begin{array}{l}\text { To obtain } \\
\text { SI units }\end{array}$ \\
\hline $\begin{array}{rl}25 & .4 \\
0.3048 \\
0.1894\end{array}$ & $\begin{array}{l}\text { millimeters }(\mathrm{mm}) \\
\text { meters }(\mathrm{m}) \\
\text { meters per kilometer } \\
(\mathrm{m} / \mathrm{km})\end{array}$ \\
\hline $\begin{array}{l}1.609 \\
2.590\end{array}$ & $\begin{array}{l}\text { kilometers ( } \mathrm{km}) \\
\text { square kilometers } \\
\left(\mathrm{km}^{2}\right)\end{array}$ \\
\hline 0.02832 & $\begin{array}{l}\text { cubiç meters per second } \\
\left(\mathrm{m}^{3} / \mathrm{s}\right)\end{array}$ \\
\hline 43.81 & $\begin{array}{l}\text { cubic decimeters per } \\
\text { second }\left(\mathrm{dm}^{3} / \mathrm{s}\right)\end{array}$ \\
\hline 0.04381 & $\begin{array}{l}\text { cubic meters per second } \\
\left(\mathrm{m}^{3} / \mathrm{s}\right)\end{array}$ \\
\hline 0.01093 & $\begin{array}{l}\text { cubic meters per second } \\
\text { per squąre kilometer } \\
{\left[\left(\mathrm{m}^{3} / \mathrm{s}\right) / \mathrm{km}^{2}\right]}\end{array}$ \\
\hline
\end{tabular}

\section{ABBREVIATIONS USED IN THIS REPORT}

BOD

CVNRA

RM
Biochemical oxygen demand

Cuyahoga Valley National Recreation Area River mile 


\title{
LITERATURE REVIEW AND NEED FOR ADDITIONAL STUDY OF SURFACE-WATER QUALITY IN THE CUYAHOGA VALLEY NATIONAL RECREATION AREA, OHIO
}

\author{
By C. J. Oblinger Childress
}

\section{ABSTRACT}

The Cuyahoga Valley National Recreation Area encompasses about 24 miles of the middle reach of the Cuyahoga River and parts of four major tributaries - Furnace Run, Brandywine Creek, Chippewa Creek, and Tinkers Creek. Water quality in this reach does not meet Ohio water-quality standards for dissolved oxygen, fecal bacteria, ammonia, and lead. Point sources and nonpoint sources of effluent contribute contaminants.

On the basis of a review of scientific and technical literature, National Park service management goals, and water-quality data collected by the U.S. Geological Survey, three subject areas for future study are suggested: (1) The dissolved oxygen regime, (2) chemical quality of base flow, and (3) quality of storm-water runoff.

\section{INTRODUCTION}

\section{Background}

The Cuyahoga Valley National Recreation Area (CVNRA) was established in 1974 under Public Law 93-555 to be administered and managed by the National Park Service. Under the act, the Park Service is responsible for developing the park to best meet the recreational needs of the surrounding urban population while maintaining or enhancing the park's natural resources and historical features. The CVNRA is located within the Akron-Cleveland metropolitan area in northeastern Ohio. It includes a 24-mile section of the lower Cuyahoga River (fig. I).

The lower reach of the river is part of the old Ohio canal system joining the Ohio and St. Lawrence River basins. The area along the river has been an industrial center for over 100 years.

Water quality in the lower reach has been the subject of intense interest over the last 15 to 20 years in an atmosphere of environmental awareness and more stringent control of wastewater discharges. Even though improved, the river is not yet suitable for water-based recreation. Bacterial counts remain too high for boating or swimming. Recurrences of low dissolved oxygen, high suspended solids, and slugs of toxic materials make it impossible for populations of game fishes to survive. 


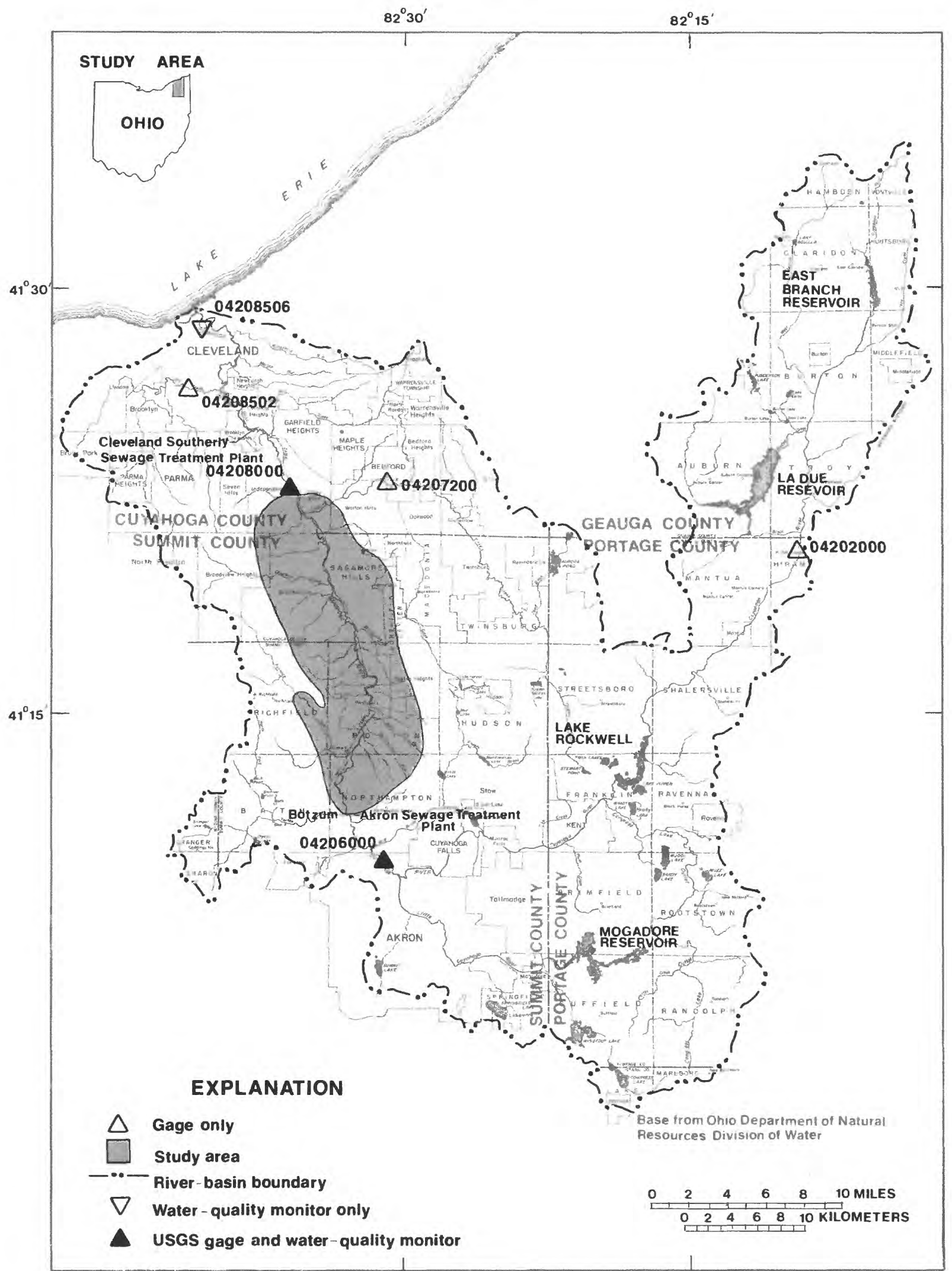

Figure 1.--Cuyahoga River Basin 


\section{Purpose and Scope}

The purpose of this report is to provide information that will enable park managers to begin studies of water-quality control alternatives for enhancing recreational activities in the park. It provides a compilation of previous water-quality investigations; shows the locations of major dischargers; lists the agencies involved in water-quality monitoring; provides a description of areal geology, hydrology, and climate; and suggests alternatives for further study of the reach of the Cuyahoga River flowing through the CVNRA.

Information presented in this report focuses on the CVNRA, which encompasses 24 miles of the Cuyahoga River between Botzum (river mile (RM) 37.3) in Summit County and the U.S. Geological Survey gaging station at Independence (RM 13.6) in Cuyahoga County (fig. 2); about one-fifth of the drainage area between those two gaging stations is considered. The topics for further study suggested herein consist of three separate elements -- a dissolved oxygen model, a study of base-flow water quality, and a study of nonpoint sources of contamination by storm runoff. Emphasis is on the impacts that existing or potential land uses within the CVNRA have on water quality in the main stem of the river.

\section{Description of the Cuyahoga River Basin}

\section{Hydrology}

The Cuyahoga River basin drains 813 square miles in northeastern Ohio. From the headwaters in Geauga County, the Cuyahoga flows south to the Lake Rockwell impoundment at Kent, southeast to Akron, and then north through the CVNRA and Cleveland, before emptying into Lake Erie. Because of its U-shaped configuration, the headwaters rise only 35 miles from the mouth (fig. 1 ).

Flow from the upper reach is impounded at Lake Rockwell, which serves as a water supply for Akron. In addition, there are three other major reservoirs in the basin, numerous low-head dams, an 80-foot hydropower dam at Cuyahoga Falls, and a canal-diversion dam near Brecksville (fig. 1).

The Cuyahoga River rises at an elevation of about 1,300 feet above sea level and drops gradually, at an average of 3 feet per mile, to an elevation of 1,050 feet at Lake Rockwell (RM 59) (fig. 3). In the middle reach of the river from Lake Rockwell to the Akron Sewage Treatment plant (RM 37.3), the slope averages 4 feet per mile to the first dam in Cuyahoga Falls and 6 feet per mile to the Akron sewage treatment plant. It is in the upper part

"leiver mile" is the distance upstream of the mouth, in miles. 




Base from US Geological Survey

Peninsula 1967, Northfield 1967, and Cleveland South 1979

Figure 2.--The Cuyahoga Valley National Recreation Area. 


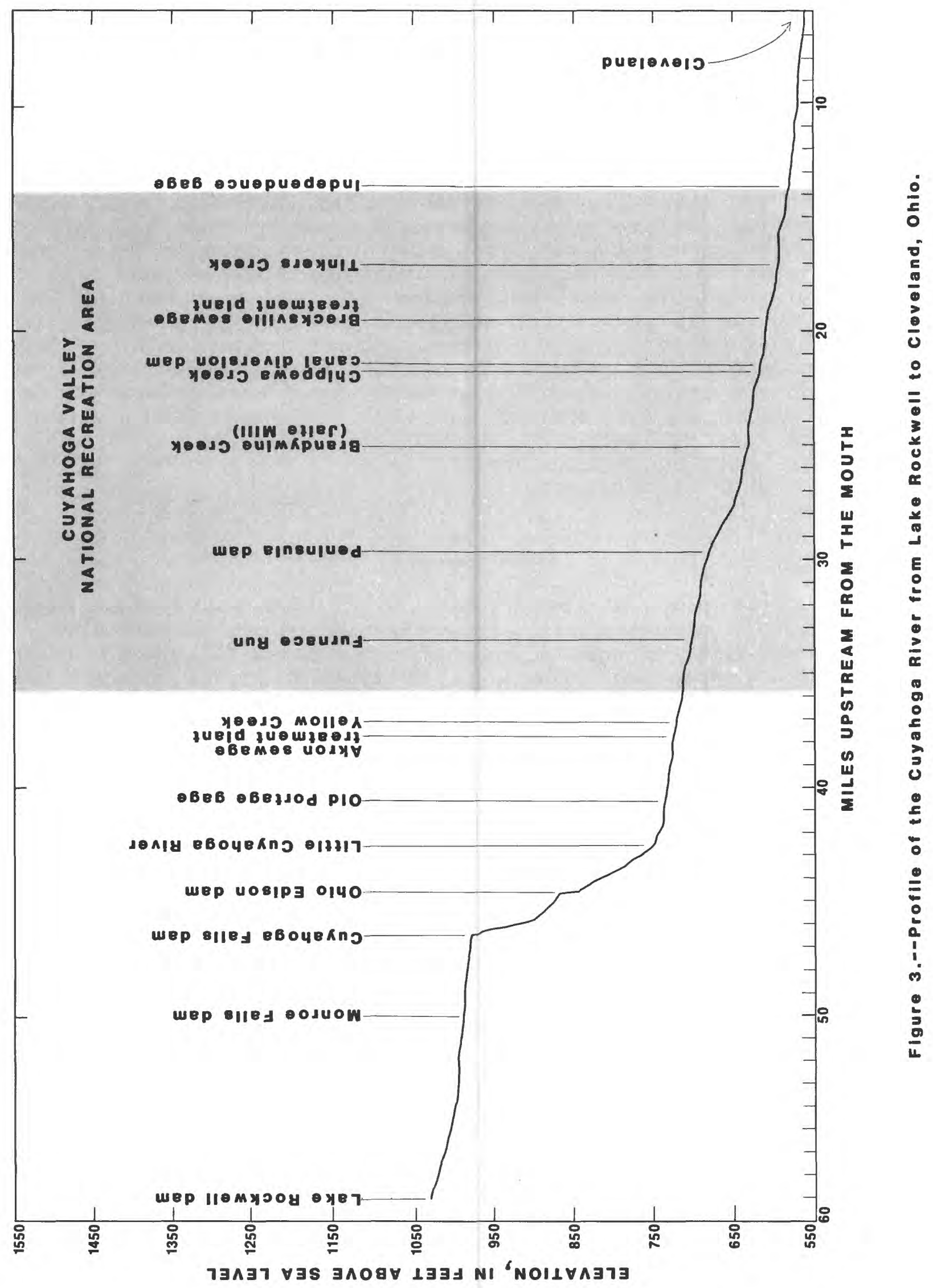


of this latter section that the river drops most sharply as it flows through the gorge. Urbanization has encroached upon the entire reach. The major tributaries in the middle reach are Breakneck Creek, Fish Creek, the Little Cuyahoga River, and Mud Run. The latter two are just upstream and just downstream, respectively, of the U.S. Geological Survey old Portage gage (fig. 1).

The lower reach of the Cuyahoga River extends from the Akron sewage treatment plant at Botzum to the mouth at Lake Erie (fig. 1). The Akron sewage treatment plant, returning most of the water that was removed at Lake Rockwell back into the main stem, has a significant impact on discharge. Discharge from the Akron sewage treatment plant averages 58 cubic feet per second. The canal dam diverts part of the flow to the ohio canal, which, in this reach, serves as a water supply to industry in Cleveland. There are six major tributaries entering the lower reach: Yellow Creek, Furnace Run, Brandywine Creek, Chippewa Creek, Tinkers Creek, and Big Creek. From Botzum to Tinkers Creek, land use is mostly residential and recreational. From Tinkers Creek to the mouth, the area is increasingly urban and industrial. The last 6 miles of the river are maintained as navigation channel by the U.S. Army Corps of Engineers.

Water Quality

The upper reach of the Cuyahoga River (headwaters to Lake Rockwell) is a clean-water reach. Here the river supports a diverse community of aquatic macroinvertebrates (Olive, 1976) and water-based recreation. The upper 24 miles have been designated "scenic river" by the Ohio Department of Natural Resources.

Water quality has been degraded in the middle reach. The towns of Kent and Cuyahoga Falls contribute industrial and urban nonpoint waste, and Rent contributes municipal point-source waste (fig. 1). The Little Cuyahoga River delivers industrial and urban nonpoint wastes into the main stem at the lower end of the middle reach. As a result, the quality of water entering the CVNRA reach is poor. Effluent from the Akron sewage treatment plant contributes an average of $90 \mathrm{million}$ gallons per day or $58 \mathrm{cubic}$ feet per second. During the summer low-flow season, the discharge from the Akron sewage treatment plant can amount to as much as two-thirds of the total flow in the main stem (Ohio Environmental protection Agency, 1981). The biological community in the lower reach consists almost entirely of pollution-tolerant species.

The section from the Akron sewage treatment plant at Botzum to Furnace Run (fig. 2) is considered grossly polluted (Ohio Environmental Protection Agency, 1980). When waste flow to the plant exceeds design capacity, the excess flow bypasses secondary treatment and some primary-treated waste is discharged directly into the river. Improvements are planned to increase biochemical capacity, reduce oxygen demand, reduce total dissolved solids, 
and, possibly, add nitrification. These improvements, however, will not be completed before 1985. In this reach, dissolved oxygen, fecal bacteria, ammonia, and lead fail to meet Ohio's water-quality standards (Ohio Environmental Protection Agency, 1981).

Below the sewage treatment plant, sludge beds form as suspended material is deposited (U.S. Army Corps of Engineers, 1981). Biochemical oxygen demand (BOD) is physically removed in this process. During periods of high flow, the sludge probably is scoured from the river bed and redeposited farther downstream after exerting some of the BOD.

The section from Furnace Run to the diversion-dam pool at Brecksville is a recovery reach. The only major point source in this reach is the paper mill at Jaite. The slope is 7 feet per mile, and traveltime between Botzum and the Peninsula dam is short. Flow is pooled at the canal diversion dam (fig. 2). The results of the steep slope and short traveltime are that (1) the deposition of suspended sediment is limited, and (2) BOD originating in the upstream reach, particularly the Akron sewage treatment plant (fig. $\lambda$ ), is exerted as far downstream as the canal diversion dam.

A long detention time in the canal diversion dam, in combination with high BOD loads and increased temperature in summer, will cause a depletion of dissolved oxygen. Therefore, a dissolvedoxygen sag ${ }^{1}$ would be expected to occur in the diversion-dam pool. The diversion-dam pool also provides the conditions necessary for deposition of suspended material.

Water quality is poor in the reach from the diversion dam to Independence. Here the slope flattens to about 5 feet per mile. Detention time is increased, as is deposition of suspended material. Two significant point sources -- the Brecksville sewage treatment plant and Tinkers Creek - add to the total suspended solids, BOD, and fecal bacterial load. Tinkers Creek, the largest tributary to the Cuyahoga, drains a heavily urbanized and industrialized area.

The condition of the biological community provides another indication of overall water quality between the Akron sewage treatment plant and Independence. The entire reach was characterized in 1974 by pollution-tolerant macroinvertebrate species. Over 95 percent of the community was composed of annelids, pulmonate snails, and diptera (Olive, 1976). The community composition remains essentially unchanged in 1981 (J. H. Olive, University of Akron, oral commun., 1981).

1 The point where the dissolved-oxygen concentration is at its lowest as oxygen demand from waste material exceeds oxygen supply. 


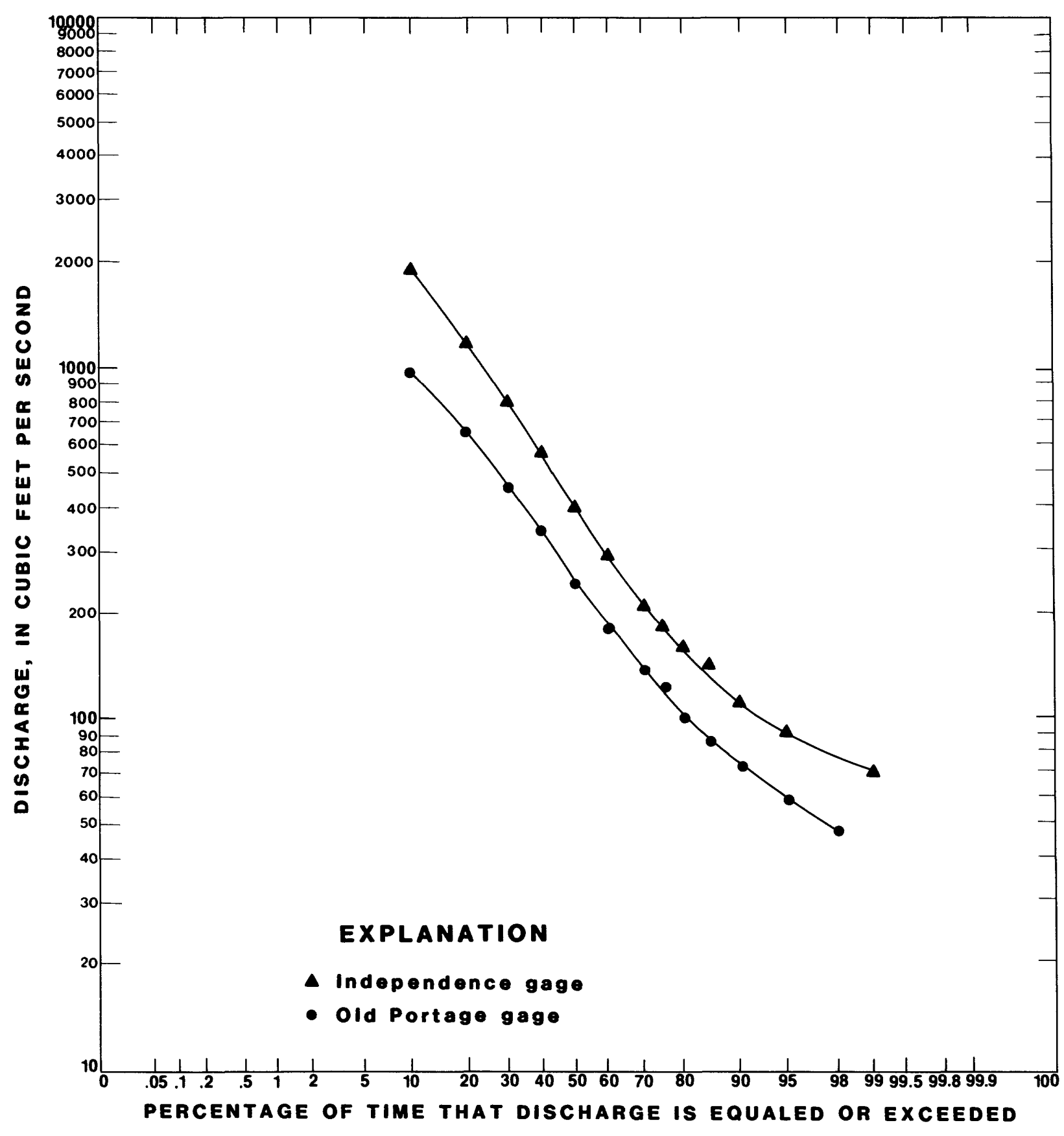

Figure 4.--Flow-duration curves for the Cuyahoga River at the Old Portage and independence gages. 


\section{Geology}

Most of the basin lies within the glaciated Allegheny Plateau. The basin from the headwaters to Rent is characterized by knob-and-kettle topography formed during the last glaciation when the ancestral river flowed over ice trapped between two end moraines. The numerous small lakes that were formed around Rent are evidence of this. The basin from Kent to Akron is characterized by buried remnants of the ancestral Cuyahoga River and of melt-water channels that flowed south and deposited large amounts of sand and gravel. At Cuyahoga Falls, the river cuts through Sharon Conglomerate sandstone, an erosion-resistant sandstone. This has resulted in the formation of the falls and cascade in the gorge in the middle reach.

The basin from Akron to the mouth encompasses the CVNRA. The surficial geology is characterized by silts and clays that were deposited when two ancestral lakes were formed by the retreating glacier, before the Cuyahoga River flowed north into Lake Erie as it now does (Rau, 1968).

\section{Climate}

Average annual precipitation is slightly less than 36 inches; 20 inches fall from April through September. Average annual snowfall is 52.5 inches. Climate is strongly influenced by Lake Erie. Precipitation increases somewhat from the Lake to the St. LawrenceOhio River divide; average annual precipitation is 34.99 inches at Cleveland, 35.13 inches at Akron, and 39.69 inches at Hiram. Temperatures in the near-shore area remain colder in summer and warmer in winter than in the inland areas (U.S. National Oceanic and Atmospheric Administration, 1978; U.S. Department of Commerce, 1959).

\section{The CVNRA and Its Management Objectives}

The Cuyahoga Valley National Recreation Area is situated between the Akron and Cleveland metropolitan areas. There was an early local interest in preserving the area as open space for recreational uses because of its natural scenic beauty. A number of metroparks were established in the area; these became known as "Cleveland's emerald necklace."

In 1974, Congress established the CVNRA under PL 93-555. That act was amended in 1976 under PL 93-578 to include additional acreage. Under the act, further land acquisitions are possible where necessary to improve park management or visual continuity. The general management plan (National Park Service, 1977) cites natural-resources management as a major goal. Furthermore, highest priority for land acquisition goes to land within the flood plain of the river. 
Although park managers acknowledge that water-based recreation in a national recreation area is desirable, they also recognize that existing water quality poses a potential health hazard, particularly because of high levels of microbial contamination.

The need for storm-water management is emphasized. Runoff produced during a storm results in flooding, erosion, and increased sediment and contaminant discharges from point and nonpoint sources.

\section{Agencies Monitoring the Cuyahoga_River}

The U.S. Geological Survey, the Ohio Environmental Protection Agency, and the Akron Water Pollution Control Division are responsible for most of the water-quality monitoring in the CVNRA area. Table 1 contains a listing of existing and discontinued U.S. Geological Survey gaging stations in the Cuyahoga River basin. Data are available in U.S. Geological Survey annual data reports and directly from the Survey's computer data base. Table 2 contains the discharge statistics for the four stations most relevant to study of the park reach. Figure 4 shows flow-duration curves for the old Portage and Independence gages. The critical low flows (the average 7-day low flow at a frequency of once in 10 years) are 44 and 63 cubic feet per second, respectively (Johnson and Metzker, 1981).

The Ohio Environmental Protection Agency maintains sampling programs at some of the U.S. Geological survey gaging stations on the main stem and on Tinkers creek. Some of the samples are taken monthly, some quarterly, and some at low flow. Data are available through the STORET data base and are interpreted annually in the 303 (b) reports available from the Ohio Environmental Protection Agency. They also maintain a compliance monitoring program; point sources are sampled for compliance with National Pollution Discharge Elimination System permits.

The Ohio Environmental Protection Agency maintains a computer listing of permitted dischargers in the Cuyahoga River basin. The major point sources discharging into the main stem and affecting water quality within the park are: Akron and Brecksville sewage treatment plants, Jaite paper mill, and Blossom Music Center (fig. 2). In addition, many of the tributaries receive waste that eventually reaches the main stem.

The Akron Water Pollution Control Division collected samples at Ira and the Akron sewage treatment plant trunkline during 1981. Field and laboratory determinations for dissolved oxygen, $\mathrm{pH}$, temperature, total phosphorus, and fecal coliforms are made five days a week. Determinations for BOD, chemical oxygen demand, metals, suspended solids, ammonia, nitrate, nitrite, turbidity, and surfactants are made once a week. Data are compiled in an annual report available from the Akron Wastewater Management Field Group. 
Table 1.--Inventery of U.S. Geological survey gages in the cuyahoga River basin

Station name and number
Type of

data

Period of record

Cuyahoga River at

Hiram Rapids

(04202000)

Temperature

Discharge ${ }^{1}$

Discharge

Discharge

Discharge

Discharge

pringfield Lake outlet

at Akron (04205000) -

Little Cuyahoga River

at Akron (04205500)

Little Cuyahoga River below Ohio Canal at

Akron (04205700) --

Cuyahoga River at Old

Portage (04206000)

Discharge

Cuyahoga River near

Mogahoga River at
Mogadore $(04204000) \ldots \ldots$

Little Cuyahoga River

at Massillon Road,
Akron $(04204500)$

Discharae

Oct. 1948 - Sept. 1949

Aug. 1927 - Dec. 1935,

Oct. 1944 - June 1982

Jan. 1946 - Sept. 1974

Oct. 1933 - Sept. 1935

Jan. 1946 - Oct. 1978
Jan. 1946 - Sept. 1949 ,
Oct. 1960 - Sept. 1974

July - Sept. 1920,

Oct. 1927 - Apr. 1934
Discharge
Oct. 1973 - Nov. 1979
Temperature
Oct. 1970 - May 1982
(discontinuous)
Discharge
Oct. 1921 - Dec. 1935,
Mar. 1939 - June 1982
Specific con-
Oct. 1970 - May 1982 ductance
Oxygen, dis- Oct. 1970 - May 1982 solved
$\mathrm{pH}$
Oct. 1970 - May 1982
Suspendęd sed-Mar. 1972 - Sept. 1981 iment $^{2}$


Table 1.--Inventory of U.S. Geological Survey gages in the cuyahoga River basin--Continued

\section{Station name and number}

Type of data

Period of record

Cuyahoga River at

Botzum (04206200)

Cuyahoga River at

Ira $(04206250)$

Cuyahoga River at

Brecksville (04206500)-

Discharge

Temperature

Jan. 1947 - Jan. 1948 ,

Oct. 1948 - Sept. 1949

Discharge

Aug. 1973 - Oct. 1979

Temperature

Mar. - Sept. 1950

Mar. 1923 - Sept. 1924

Ohio Canal feeder at

Brecksville (04207000)-

Discharge

Mar. 1923 - June 1924

Tinkers Creek at

Bedford (04207200)

$\begin{array}{ll}\text { Discharge } & \text { Dec. } 1962-\text { Apr. } 1982 \\ \begin{array}{c}\text { Suspended sed- Mar. - June 1972, } \\ \text { iment }\end{array} & \text { Jan. } 1974 \text { - Sept. } 1979\end{array}$

Ohio Canal at Inde-

pendence (04207500)----

Discharge

$$
\begin{aligned}
& \text { Oct. } 1921 \text { - May } 1923, \\
& \text { Aug. } 1927 \text { - Dec. } 1935, \\
& \text { Oct. } 1940 \text { - Sept. } 1941, \\
& \text { Oct. } 1948 \text { - June } 1981
\end{aligned}
$$

Cuyahoga River at Independence $(04208000)$
Temperature Oct. 1956 - June 1982
(discontinuous)
Discharge
Oct. 1921 - May 1923,
Oct. 1927 - Dec. 1935,
Apr. 1940 - June 1982
Specific con- July 1965 - June 1982 ductance
Oxygen, dis- July 1965 - June 1982 solved
$\mathrm{pH}$
Feb. 1973 - June 1982
Suspended sed-Oct. 1950 - Sept. 1981 iment


Table 1.--Inventory of U.S. Geological Survey gages in the Cuyahoga River basin--Continued

Station name and number
Type of data
Period of record

Big Creek at Cleveland

(04208502)

Discharge $\quad$ Oct. 1972 - Apr. 1982
$\begin{gathered}\text { Suspended sed- Feb. } 1972 \text { - Sept. } 1978 \\ \text { iment }\end{gathered}$

Cuyahoga River at DuPont

Intake, Cleveland

(04208505) -

$\begin{array}{ll}\text { Specific con- Oct. } 1964 \text { - Jan. 1967, } \\ \text { ductance } & \text { Mar. } 1967 \text { - Apr. 1975 }\end{array}$

Cuyahoga River at W. 3d

St. Bridge, Cleveland

(04208506) -

$$
\begin{array}{ll}
\text { Temperature } & \text { Nov. } 1966 \text { - June } 1982 \\
\begin{array}{c}
\text { Specific con- } \\
\text { ductance }
\end{array} & \text { Nov. } 1966 \text { - June } 1982 \\
\begin{array}{c}
\text { Oxygen, dis- } \\
\text { solved }
\end{array} & \text { Nov. } 1966 \text { - June } 1982 \\
\mathrm{pH}^{4} & \text { Nov. } 1966 \text { - June } 1982
\end{array}
$$

Cuyahoga River at Center

St. Bridge, Cleveland

(04208510) -- - - - - - -

$$
\begin{array}{ll}
\text { Temperature } & \begin{array}{l}
\text { Oct. 1964-Nov. } 1966 \\
\text { (discontinuous) }
\end{array} \\
\begin{array}{c}
\text { Specific con- } \\
\text { ductance }
\end{array} & \begin{array}{l}
\text { Oct. } 1964 \text { - Nov. } 1966 \\
\text { (discontinuous) }
\end{array} \\
\begin{array}{c}
\text { Oxygen, dis- } \\
\text { solved }
\end{array} & \begin{array}{l}
\text { Oct. 1964- Nov. } 1966 \\
\text { (discontinuous) }
\end{array} \\
\text { pH } & \begin{array}{l}
\text { Oct. 1964- Nov. } 1966 \\
\text { (discontinuous) }
\end{array}
\end{array}
$$

I"Discharge," mean daily water discharge.

2 "suspended-sediment," mean daily suspended-sediment concentration and discharge.

3 some missing record in 1967 .

${ }^{4}$ Some missing record in 1967 and 1968 . 







\section{Chemical Quality}

Water quality in the Cuyahoga River has been well documented during the past 25 years. A number of large-scale sampling studies (including studies for several dissolved-oxygen models) have been conducted in the middle and lower basins.

The U.S. Public Health Service (1951) published a report on the Lake Erie basin, which includes the Cuyahoga River sub-basin. The report lists existing wastewater treatment facilities, the types of dischargers served, and adequacy of treatment at each facility.

In 1954 and 1956, the Ohio Department of Health undertook an intensive survey of water quality in the main stem (Ohio Department of Health, 1960). Samples were collected at 79 sites on the river, on its major tributaries, and from all major municipal and industrial discharges. Samples were analyzed for chemical oxygen demand, BOD, phenols, oil, pH, alkalinity, acidity, total solids, suspended solids, and various metals. During the study, instream dissolved oxygen dropped below 1.0 milligrams per liter (mg/L) just below the Akron sewage treatment plant, and recovered at the confluence with Tinkers Creek (RM 16). Dissolved oxygen dropped again from RM 15 to the mouth.

The following major pollution problems were reported for the river below Akron (U.S. Department of the Interior, 1968):

1. Dissolved solids

2. Bacteria

3. BOD

4. Color, floating debris, and oil.

In that report, the Federal water Pollution Control Board concluded that low flow should be augmented by at least 100 cubic feet per second to improve stream quality during that period. It was recommended that secondary treatment be improved, in some cases, with the addition of tertiary treatment.

Only a few "rough" species of fish were reported in the river below Akron. Data taken from the U.S. Geological Survey gage at Independence for the 1966 water year showed that dissolved oxygen fell below $4.0 \mathrm{mg} / \mathrm{L}$ for much of the low-flow period and, at times, fell to zero. The dissolved oxygen profile indicates that a sag occurs at RM 35 and at the canal diversion-dam pool (RM 22). Recovery takes place up to RM 14. From RM 14 to the mouth, dissolved oxygen again falls.

Trace metals were not reported in high concentrations in the river. Bacterial counts were reported as extremely high for all points downstream of Lake Rockwell. 
Havens and Emerson, Ltd. (1968), collected water-quality samples once a day from the end of June 1967 to the end of August 1967 at 43 sites on the main stem and major tributaries. Samples were analyzed for BOD, chemical oxygen demand, total and suspended solids, ammonia, nitrite, nitrate, chloride, sulfate, phosphate, and fecal and total coliform bacteria. Some trace-metal analyses and bioassays also were performed. Biological conditions were qualitatively assessed at each site. Data on industrial and municipal waste-discharge loads were obtained from plant operating records and through interviews with operators.

Discharge measurements were not made concurrent with water quality sampling, therefore, consitituent loads had to be estimated from U.S. Geological survey gage recordings of discharge.

The data were used to calibrate a dissolved oxygen model formulated from the basic Streeter-Phelps model (Velz, 1970). The model did not include the capability for modeling the processes of sediment oxygen demand, nitrification, or photosynthesis/respiration. Atmospheric reaeration was not measured in the field, but was estimated by general correlations. This can result in an underestimation of oxygen demand and a compensating overestimation of reaeration.

On the basis of the model simulation and other chemicalquality data, Havens and Emerson concluded that the reach between the Akron sewage treatment plant and Furnace Run was a degraded assimilation zone and that the reach between Furnace Run and the Cleveland Southerly sewage treatment plant (near the mouth) was a recovery zone that was unable to self-purify because of heavy loading and the depressive effect of the diversion-dam pool. They recommended that waste water treatment be improved, that the discharge of toxic wastes be prohibited, and that the prohibition be enforced.

A dissolved-oxygen model also was prepared in 1977 for Northeast Ohio Area Coordinating Agency by Eco-Labs, Inc. (1978). The model was formulated from the basic Streeter-Phelps model, but included capability for modeling nitrification (which was found to be significant), photosynthesis/respiration, and sediment oxygen demand. The latter two processes were not measured in the field but were estimated within the model to balance the oxygen budget. Reaeration also was not determined from field measurement. Discharge was estimated from U.S. Geological Survey gage record and measurement of depth made at the time of water-quality sampling. 
A third dissolved-oxygen simulation was developed for the river between Akron and the mouth (Bentley and others, 1975). The conclusion based on the model simulation was that runoff and sediment oxygen demand would result in a dissolved-oxygen sag in the navigation channel, even after the Akron and Cleveland Southerly sewage treatment plants had been upgraded as planned (at that time, by 1978). Like the two other simulations, this one depended on existing data rather than data obtained by simultaneous field measurement of each model variable. The following recommendations were made regarding future study based on the simulation results.

1. A detailed study of the physical, chemical, and biological systems should be made.

2. More accurate measurements of reaeration, nitrification, and deoxygenation coefficients are needed.

3. Nonpoint sources should be considered.

All of these models suffer from the same limitations. Many constituent values and reaction rates were not empirically measured but were estimated from existing data. As a result, calibration and verification of the models were based on data that were not collected simultaneously. Therefore, the models may not represent conditions as they exist in the river at any given time. Such models may inadequately simulate, or even fail to simulate, one or several significant processes such as reaeration, nitrification, or sediment oxygen demand.

Olive (1976) collected chemical, physical, and biological data monthly during the 1974 water year. 1 Results were compared to Ohio water-quality standards, and violations for lead $10.1 \mathrm{mg} / \mathrm{L}$ at Brecksville), fecal bacteria $(10,000$ colonies per $100 \mathrm{milli-}$ liters below Akron), and ammonia-nitrogen $(7.1 \mathrm{mg} / \mathrm{L}$ between Akron and Brecksville) were reported.

\section{Biological Quality}

White (1975) reported the findings of a study of the fish fauna in the three rivers watershed area (the Rocky, Chagrin, and Cuyahoga Rivers) between 1971 and 1974. Recommendations included improved industrial and municipal waste treatment and erosion control measures. The report noted that insufficient dissolved oxygen is not the only factor precluding healthy fish populations. Other factors are organic material from domestic waste, toxic inorganic wastes, suspended sediment from point and nonpoint sources, and thermal waste. Aquatic vegetation for spawning and food supply also is damaged by excess waste loadings. Of 107 species of fish reported historically in the three rivers watershed,

loctober 1, 1973 through September 30, 1974. 
86 were still present in 1974. Most inhabited the headwater reaches. Only pollution-tolerant species were reported as abundant below Akron; diversity was zero in the navigation channel (RM 7 to the mouth). The report contains an extensive bibliography and provides baseline information on populations at the time of the study.

Fish fauna were sampled by Northeast Ohio Area Coordinating Agency (1978) at 46 sites in the main stem and tributaries from the headwaters to the mouth. The species collected were compared with those historically reported or expected in a similar, but clean, water reach. The results were consistent with other similar surveys. The reach between Akron and the mouth was degraded. The section from Akron to the upstream boundary of CVNRA was one of the most degraded in that agency's planning area. Two tributaries, Furnace Run and Tinkers Creek, were reported as being of particularly poor habitat quality.

Olive (1976) reported only pollution-tolerant species of macroinvertebrates in the reach below Akron (annelids, pulmonate snails, and diptera), as compared to a fairly diverse clean-water community above Lake Rockwell.

\section{Basin Inventories}

There are a number of basin inventories containing compilations and interpretations of data. One of the earlier reports lists existing sewage treatment plants, types of treatment, and future waste-treatment needs (Ohio State Planning Board, 1936).

An inventory of water resources in Cuyahoga County was published in 1953 (Winslow and others) by the Ohio Department of Natural Resources. The report includes a description of the county's geology, quality and quantity of ground water, streamflow characteristics (based on continuous record from U.S. Geological Survey stream gages), and water quality (based on field samples collected between March 1950 and February 1951 at two stations, Brecksville and the Center street Bridge in Cleveland). The low-flow characteristics of the Cuyahoga River and Tinkers Creek were analyzed from measurements taken at 30 stations in October 1948 and August 1951.

The Cuyahoga River basin report was the first in a series of water inventories for the State of Ohio (Frost, 1959). The report concluded that ample water supplies existed in the basin, but that a continued effort to improve treatment of industrial and municipal wastes was vital. Other recommendations were:

1. More inland water and park recreation areas.

2. Reservoirs to increase sustained yield.

3. Improved land management to reduce erosion. 
Basing his conclusions on data from the Ohio Department of Health study (1960), Frost characterized the Cuyahoga River below the city of Akron to the mouth as being of fair quality, "generally unsuitable for domestic and many industrial uses unless appropriately treated."

A soil survey for Cuyahoga County is available from the U.S. Soil Conservation Service (U.S. Department of Agriculture, 1980). Included are detailed maps of soil types as well as information on soil use and management.

An inventory of ground-water resources in summit County was published in 1953 (Smith and White, 1953).

The Ohio Department of Health, Division of Engineering (1968), compiled existing water-quality data for the Cuyahoga River and made the following comments and recommendations based chiefly on a Federal water Pollution Control Board study.

1. Major pollution problems were dissolved solids; biochemical, chemical, and sediment oxygen demand; bacteria; nutrients; color; floating debris; and oil.

2. Critical areas were downstream of the Akron sewage treatment plant and downstream of the Cleveland Southerly sewage treatment plant.

3. Flow must be augmented by at least 100 cubic feet per second to meet the minimum criteria for recommended use below Akron.

4. Nutrient control from point and nonpoint sources should be used to reduce algal growths.

5. Programs should be encouraged to reduce silt problems.

The report contains a compilation of quantities and type of discharges from municipal and industrial dischargers.

In 1968, a symposium was held at Rent State University. Included in the symposium publication are papers that provide background information on Cuyahoga basin geomorphology (Rau, 1968), water quality (Simpson, 1968), and fishes in the upper basin (Orr, 1968).

Northeast Ohio Area Coordinating Agency has compiled a great deal of basin information. Its publications include an inventory of dischargers, sewage treatment plant load and flow projections, rainfall data, an analysis of $f$ ish habitat and a list of species collected, and a listing of water-quality monitoring agencies. 


\section{Erosion, Sedimentation, and Flooding}

The U.S. Army Corps of Engineers, Buffalo District, published a series of reports in 1968 on the flooding of the Cuyahoga River and its major tributaries between Hiram Rapids and the mouth. The series reports frequency and magnitude of flooding, preventive measures, basin descriptions, and channel profiles and cross sections.

In 1971, they published the first interim report of the Cuyahoga River Restoration Study. The report includes the results of two studies previously mentioned (Havens and Emerson, Ltd., 1968; U.S. Army Corps of Engineers, Buffalo District, 1968), a detailed description of recreational potential in what is now the CVNRA area, preliminary work on erosion and sedimentation.

After receiving public comment on this first interim report, the Corps elected to concentrate further effort on erosion and sedimentation (U.S. Army Corps of Engineers, Buffalo District, 1977). The results of that study were published in 1981 (U.S. Army Corps of Engineers, Buffalo District). The Corps concluded that the source of most of the sediment deposited in Cleveland Harbor $(530,000$ tons per year) was not the main stem, as anticipated, but upland areas of the basin between the Akron sewage treatment plant and Independence.

Their estimates were based on the Universal Soil Loss Equation and not on hydrologic data. The Universal Soil Loss Equation was developed for use on agricultural watersheds to estimate the quantity of soil dislodged from the land surface by rain or runoff. It does not measure the quantity delivered to the stream. The Corps estimated that the proportions of dislodged soil reaching the stream were 10 percent for pastureland, 20 percent for cropland, 50 percent for commercial-industrial land use, and 70 percent for woodland. The last figure is a much higher delivery rate than would normally be expected for an area protected with vegetative cover.

Hydrologic data do not support these conclusions. Suspendedsediment data collected between November 1, 1976, and October 30 , 1977, show that only 235,000 tons of suspended sediment passed the Independence gage (U.S. Army Corps of Engineers, 1981, appendix E2); the average load, based on 10 years of data, is 211,000 tons per year past the Independence gage (Apmann, 1981). 
Although violations of water-quality standards have been less frequent and less dramatic than in the past, violations still do occur. For example, figures 5 and 6 represent minimum daily dissolved oxygen concentration at two U.S. Geological Survey gages during the 1972 and 1981 water years. Minimum dissolved oxygen during the summer months has, on the average, increased over those 9 years at both stations, but the standard of $4 \mathrm{mg} / \mathrm{L}$ for the Cuyahoga River has not always been maintained. As the most visible point sources are improved, such as the Akron sewage treatment plant, attention must be turned to the less visible but equally important nonpoint sources. These ultimately will be the limiting factors in meeting state and federal water-quality standards.

On the basis of existing data and previous studies, the major water-quality problems can be summarized for the reach between Bath Road and Independence:

1. The impacts of erosion in the reach on sediment deposition in the navigaton channel are uncertain. Accurate measurements of sediment yield in relation to land use are needed.

2. Industrial and municipal point sources contribute effluents characterized by excessive biochemical and chemical oxygen demand, bacteria, total suspended solids, and trace metals. During low flow, point sources may contribute as much as two-thirds of the total flow.

3. Flow is impounded at Lake Rockwell, the water supply for Akron. There is no requirement for maintenance of a minimum flow from the reservoir, therefore, flow out of Lake Rockwell may be entirely cut off, or nearly so, in summer. This exacerbates an already critical lowflow situation farther downstream where ground-water seepage becomes the only clean water source.

4. The river does not support a diverse aquatic community. This may be due to low dissolved oxygen, toxic slugs, and destruction of habitat due to sedimentation.

5. The extent of chemical contamination contributed by nonpoint sources (land use) is unknown.

The following three elements are suggested as possibilities for future study on the basis of recommendations from previous work and the National Park Service's goals for the CVNRA:

1. Dissolved-oxygen regime -- Develop a dissolved-oxygen model for the main stem to simulate the effects of various water-quality control alternatives on dissolved oxygen during critical low-flow periods. 


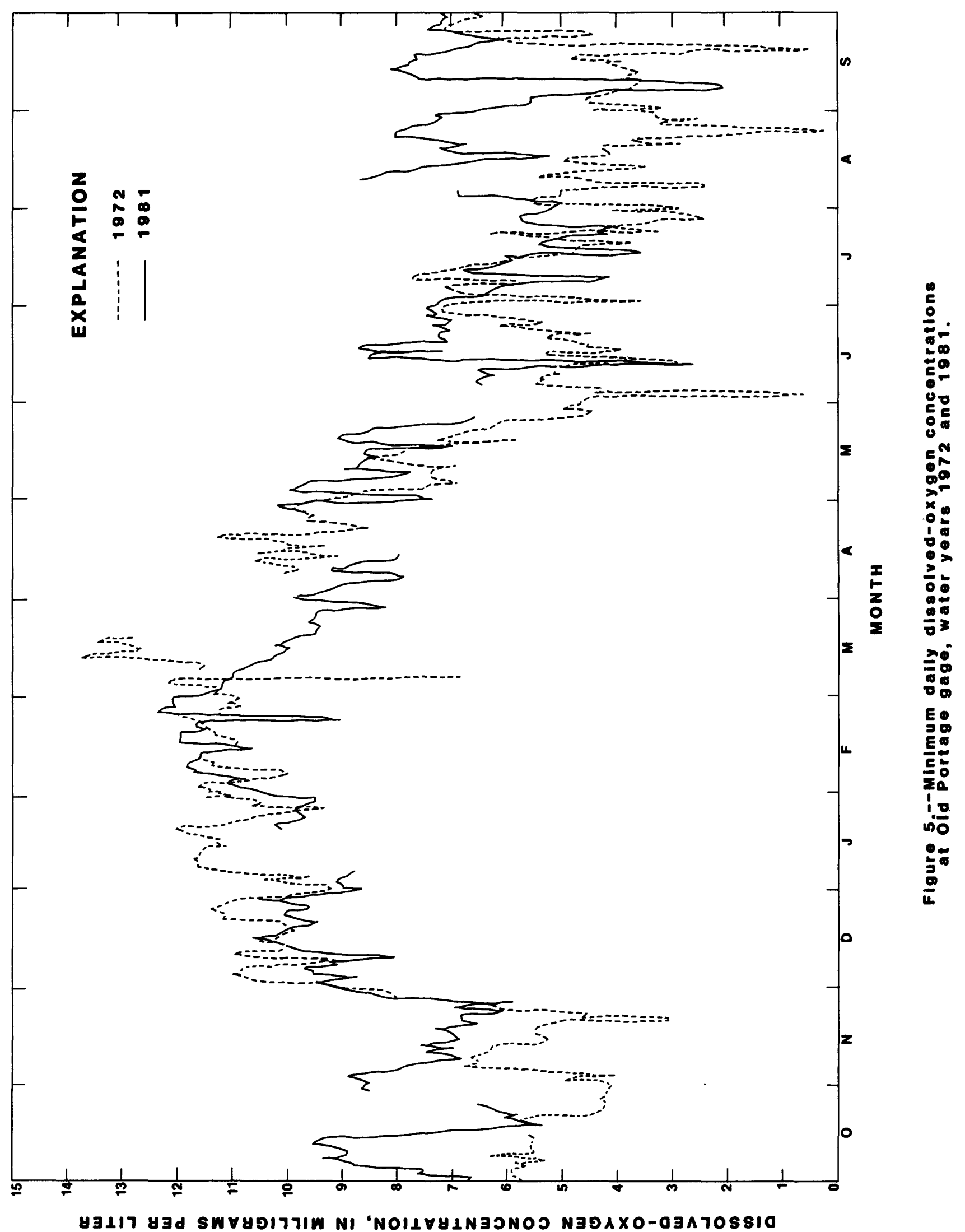




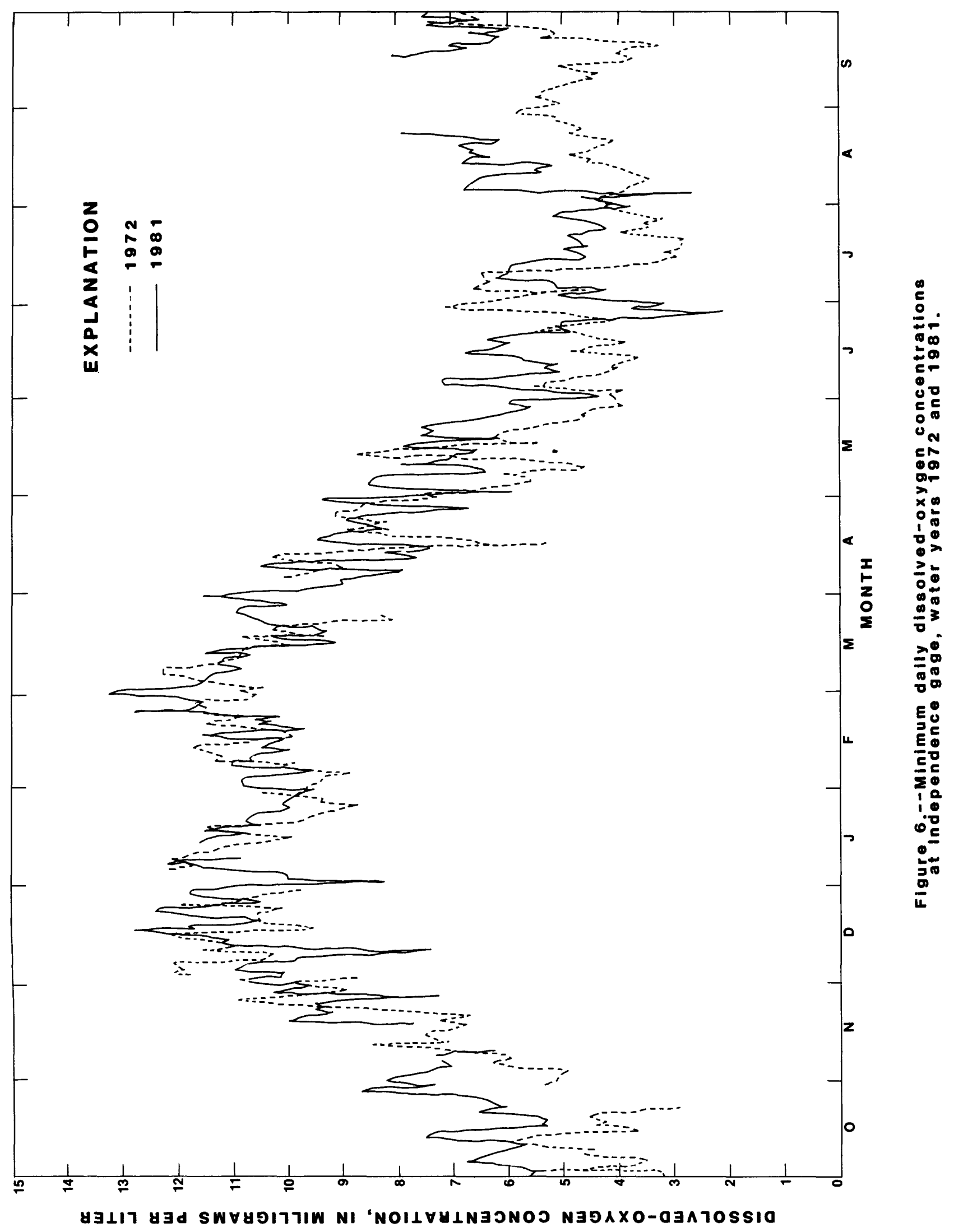


2. Base-flow quality and quantity -- Determine the effect of land uses within the park on water quality during critical low-flow periods.

3. Quality of storm-water runoff -- Identify nonpoint sources of contamination and relate them to land uses within the park.

Most of the existing water-quality data in the study area (the Cuyahoga River basin between Botzum and Independence) are from monitoring stations. Although monitoring data are useful for observing general water-quality trend, they have limited usefulness for defining cause-and-effect relationships. Defining such relationships requires data that have been collected simultaneously under specified conditions to minimize variations in collection technique, analytical technique, and hydrologic and climatic conditions. For this reason the approach to each of the three suggested elements includes an intensive data-collection effort.

\section{Dissolved-oxygen Regime}

Temporal and spatial variations in dissolved oxygen concentrations are functions of channel morphology, hydrology, biological, physical, and chemical characteristics, and interactions. The dissolved-oxygen model represents each of these characteristics and interactions mathematically, enabling the user to make predictions about dissolved oxygen based on expected or chosen conditions.

The modeling process consists of three steps -- data collection, model calibration, and model verification. Data collection is a crucial step. Models are commonly calibrated with data that have been collected to measure water-quality trends. Waterquality monitoring data reflect conditions over a wide temporal range; as a result, the data do not reflect the cause-and-effect relationships that must be defined to accurately model a process.

The factors that determine instream dissolved oxygen concentration are: (1) Hydrology, (2) hydraulics, (3) oxygen sources, (4) oxygen sinks, and (5) temperature effects (Krenkel and Novotny, 1979). Hydrologic factors include flow and temperature. Hydraulic factors are those related to stream morphology such as channel slope, width, and depth; traveltime; and bed material. Oxygen sources include atmospheric reaeration and photosynthesis. Oxygen sinks include respiration; unoxidized nitrogenous compounds (such as ammonia and nitrite); and sediment, chemical, and biochemical oxygen demand. BOD is a function of sources and sinks. Point sources of BOD include municipal sewage treatment plants and industry; nonpoint sources include local runoff, primary productivity, and channel scour. BOD sinks include sedimentation (a source of SOD) and removal by biological slimes. Temperature effects are those related to reaction rates. The rates of BOD, sediment oxygen demand, nitrification, photosynthesis, respiration, and reaeration are all temperature dependent. 
Once these factors have been mathematically quantified, the resulting model can be used as a planning tool for basin managers. The results of potential management decisions can be predicted accordingly, and management policy can be set based on the model simulations.

Specific objectives for such a study might be:

1. Define the spatial and temporal variations in water quality during two different low-flow regimes.

2. Calibrate and verify a steady-state, one-dimensional dissolved-oxygen model, and

3. Develop predictive tools from dissolved-oxygen computer simulation that can be easily used for water-resource planning within the park.

In general. it is desirable to use the simplest model that will accurately describe a given hydrologic system. A steadystate one-dimensional dissolved-oxygen model should adequately describe the Cuyahoga River system within the CVNRA. A steadystate system assumes no storage of flow; flow into the reach is equal to flow out of the reach. The record from the canal gage shows that diversion from the main stem into the canal is a fairly constant 62 cubic feet per second. A one-dimensional system assumes that each chemical constituent is uniformly distributed within a cross section.

The model would ideally include capability for modeling photosynthesis, respiration, sediment oxygen demand, reaeration, and nitrification. All of these processes are expected to have a significant effect on dissolved oxygen in the CVNRA reach because of the high nutrient and solids loads from sewage treatment plant effluent. Data for calibrating the model could be collected independently of verification data under different low-flow regimes within a single year.

Park managers could be provided with graphs and tables for interpreting the model. With these tools, managers would be able to predict the impact that changes in point-source loadings of nutrients. increased temperature, or changes in flow regimes would have on dissolved oxygen in the main stem.

\section{Base-Flow Quality}

In terms of water quality, the summer base-flow period is critical in the CVNRA reach of the Cuyahoga River. Flow from tributaries decline. and flow out of Lake Rockwell is sharply reduced so that flow in the main stem is largely waste effluent supplemented by ground-water seepage. As a result. the contaminant concentrations in the main stem are very high. If the quality of ground-water seepage is quite low in proportion to the quantity of effluent, then supplemental flow out of Lake Rockwell 
could potentially have a very positive impact on base-flow water quality. In addition, water temperature rises in summer, which increases biological reaction rates such as biochemical and sediment oxygen demand, photosynthesis, respiration and biological growth. However, the saturation concentration of dissolved oxygen is lower, thus the supply of dissolved oxygen decreases with increased temperature.

Land uses within the park are undoubtably contributing to the waste load. For instance, individual waste-disposal systems, such as septic tanks, may introduce fecal bacterial or nutrients to the river through ground-water seepage. Fertilizers applied to agricultural land may ultimately reach the river by way of groundwater seepage.

The available data are inadequate to assess the relative relationship between respective land uses within the park and base-flow quantity and quality. Quantity of seepage to the main stem from ground water was measured in 1948 and 1951 (Winslow and others, 1953). However, this study was restricted to Cuyahoga County. Many of the small tributaries draining the CVNRA were not included.

Possible objectives for this study element might be:

1. Determine the proportion of base flow in the study area that is from ground water and the proportion due to effluents, and

2. Assess the effects of land use in the study area on existing water quality in the park during base flow.

Ground-water seepage could be measured at base flow during an extended dry period and when there is no flow out of Lake Rockwell. This can be done by measuring discharge concurrently on all tributaries, point sources, and at points along the main stem. If pointsource discharges are accounted for, a gain in discharge when there is no runoff can be. attributed to seepage from ground water.

In order to meet the second objective, the study area could be divided into sub-basins, each sub-basin being characterized by fairly homogeneous land use (agricultural, commercial, industrial, residential, or woodland).

\section{Storm-Water Runoff}

The National Park Service (1977) considers storm-water management a top priority in the CVNRA. The first flush of a storm event washes accumulated material from the land surface into nearby streams. If any of this material is toxic to the aquatic community or exerts enough oxygen demand to cause dissolved oxygen to drop below levels that sustain the biota, a diverse aquatic community cannot develop. This latter problem was, in fact, observed by Bentley (1976) in a dissolved-oxygen simulation for the navigation channel. 
Although the chemical quality of the Cuyahoga River has improved somewhat, a diverse aquatic community has yet to become established. This is almost certainly caused by the silt load, which destroys habitat and spawning areas, and by toxic, combinedsewer overflows from Akron. It may also be the result of sudden rises in contaminant loads (from nonpoint sources) that may occur during storm events.

A study of this type would address the question of quality of runoff from nonpoint sources within the park during storm events and the relationship to land use within the park.

Possible objectives for this study element might be:

1. Measure the quality of storm-water runoff from nonpoint sources within the CVNRA, and

2. Relate water quality to associated land uses within the park; this will provide park managers with a tool for evaluating past and future land-use decisions.

In order to meet the first objective, a preliminary study could be conducted to verify the existence of a storm-water runoff quality problem within the study area. This would be a simple inflow-outflow study.

Three gages could be used to monitor flow and water quality, and automatically collect water and sediment samples during storm events. Input to the park reach could be measured at a gage at Ira Road. Because the diversion-dam pool acts as a sink, a gage at this intermediate point could be used to measure the amount of loss to the system at the pool. The present gage at Independence be used to monitor the outflow from the system.

If a preliminary study were to show that a significant stormwater runoff quality problem exists within the park, the study could move into a second phase. The study area could be divided into sub-basins so that land use within each sub-basin is well defined and as homogeneous as possible. Gaging stations would be located in each sub-basin and equipped to collect water samples automatically. The approach would be similar to that of the preliminary study, but would be on a much larger scale so that contributing sub-basins could be identified. 


\section{SUMMARY}

A review of the literature concerning the water quality of the Cuyahoga River shows that the major problems in the lower reach are erosion and sedimentation in the navigation channel; excessive biochemical and chemical oxygen demand, bacterial contamination, suspended solids, and trace metals from industrial and municipal point sources; lack of flow from upstream (Lake Rockwell) to supplement base flow and dilute waste effluents during the summer; a stressed aquatic community; and potential contamination from storm-water runoff.

Based on those findings, three topics for future study of the lower reach are suggested: (1) The dissolved-oxygen regime, (2) water quality and quantity during base flow, and (3) the quality of storm-water runoff.

\section{REFERENCES}

Apmann, R. P., 1981, Erosion and sedimentation in the Cuyahoga River basin, in Cuyahoga River, Ohio Restoration Study, Third interim preliminary feasibility report on erosion and sedimentation: U.S. Army Corps of Engineers, Appendix E, p. 1-48.

Bently, E. M., Jackson, V. L., Khadye, J. A., and Ramm, A. E., 1975, Water pollution investigation; Cuyahoga River and Cleveland area: U.S. Environmental Protection Agency, $\mathrm{EPA} / 905 / 9-74 / 012,142 \mathrm{p}$.

Eco-labs, Inc., and GMP Associates., Inc., 1978, Low flow dissolved oxygen model calibration, Cuyahoga River and Tinkers Creek segments: $140 \mathrm{p}$.

Frost, S. L. and Smith, R. C., 1959, Water inventory of the Chagrin and Cuyhoga River basins, Ohio, volume 1 , basin review: Ohio Department of Natural Resources Division of Water, $90 \mathrm{p}$.

Havens and Emerson Ltd., 1968, Study on Cuyahoga River water quality (for the Three Rivers Watershed District): $148 \mathrm{p}$.

Johnson, D. P. and Metzker, K. D., 1981, Low-flow characteristics of Ohio streams: U.S. Geological Survey Open-file Report 81-1195, 285 p.

Krenkel, P. A. and Novotny, V., 1979, Basic approach to water quality modeling, in Hsieh Wen Shen, ed., Modeling of rivers: New York, Wiley, p. 17/1-17/22.

Northeast Ohio Areawide Coordinating Agency, 1978, 208 area report, Technical appendices. 
Ohio Department of Health, Division of Engineering, 1968, Report on recommendations on water quality for the Rocky, Cuyahoga, Chagrin, and Grand Rivers and their tributaries.

Ohio Department of Health, Division of Sanitary Engineering, 1960, Report of water pollution study of the Cuyahoga River basin, 1954-1956.

Ohio Environmental Protection Agency, 1980, Cuyahoga and Chagrin River basin, Sub-basin Summary: 305 (b) report, IV, p. 43-54.

Ohio State Planning Board, 1936, Drainage basin studies, State of Ohio.

Olive, J.H., 1976, Chemical-physical and biological assessment of water quality in the Cuyahoga River (1973-1974): Ohio Journal of Science, v. 76 , no. 1, p. 5 .

Orr, L. P., 1968, Fishes of the Upper Cuyahoga River, in Cooke, G. D., ed., The Cuyahoga River watershed; Proceedings of a symposium held at Kent State University: p. 57-86.

Rau, J. L., 1968, Evolution of the Cuyahoga River, its geomorphology and environmental geology, in Cooke, G. D., ed., The Cuyahoga River Watershed; Proceedings of a symposium held at Kent State University: p. 9-40.

Simpson, G. D. and Curtis, L. W., 1969, Present water quality in the Cuyahoga River: Chemical Engineering Progress Symposium Series, Water -- 1969j, p. 64-74.

Smith, R. C. and White, G. W., 1953, Ground-water resources of Summit County, Ohio: Ohio Department of Natural Resources Division of Water Bulletin 27, $130 \mathrm{p}$.

U.S. Army Corps of Ėngineers, Buffalo District, 1968, Flood plain information, Cuyahoga River, Cuyahoga County, Ohio, $61 \mathrm{p}$.

---., 1969, Flood plain information, Cuyahoga River, Summit County, Ohio: $47 \mathrm{p}$.

, 1971a, Flood plain information, Cuyahoga River, Akron to Summit-Portage County line, Ohio: $53 \mathrm{p}$.

-.-., 1971b, Cuyahoga River, Ohio Restoration Study, First Interim report.

----, 1977, Cuyahoga River Restoration Study, revised plan of study.

----, 1981, Cuyahoga River, Ohio Restoration Study, Third interim feasibility report on erosion and sedimentation, v. 3 . 


\section{REFERENCES--Continued}

U.S. Department of Agriculture, Soil Conservation Service, 1980, Soil survey of Cuyahoga County, Ohio: $157 \mathrm{p}$.

U.S. Department of Commerce, 1959, Climates of the States -Ohio.

U.S. Department of the Interior, National Park Service, 1977, Cuyahoga Valley National Recreation Area, Ohio; final general management plan: $107 \mathrm{p}$.

U.S. National Oceanic and Atmospheric Administration, 1978, Climatological data, annual summary, Ohio: $15 \mathrm{p}$.

U.S. Public Health Service, Division of Water Pollution Control, 1951, Lake Erie drainage basin report.

Velz, C. J., 1970, Applied Stream Sanitation: New York, WileyInterscience, p. 137-233.

White, A. M., Trautman, M. B., Foell, E. J., Kelty, M. P., and Gaby, R., 1975, Water quality baseline assessment for the Cleveland area, Lake Erie, Volume II; the fishes of the Cleveland metropolitan area: U.S. Environmental Protection Agency 905/9-75-001, $200 \mathrm{p}$.

Winslow, J. D., White, G. W., and Webber, E. E., 1953, The water resources of Cuyahoga County, Ohio: Ohio Department of Natural Resources Division of Water Bulletin 26, 123 p. 